\title{
Survival of Erwinia amylovora on Surfaces of Materials Used in Orchards
}

*Corresponding author

Tel: +82-33-250-6432

Fax: +82-33-259-5558

E-mail: dhp@kangwon.ac.kr

ORCID

https://orcid.org/0000-0001-8486-9544

Received June 12, 2019

Revised June 16, 2019

Accepted June 16, 2019

\author{
Hyun Ju Choi, Yeon Ju Kim, Yeon-Jeong Lim, and Duck Hwan Park ${ }^{*}$ \\ Applied Biology Program, Division of Bioresource Sciences, Kangwon National University, Chuncheon \\ 24341, Korea
}

\begin{abstract}
Fire blight disease caused by the bacterium, Erwinia amylovora, was observed in apple and pear orchards in Korea in 2015. Since then, it has spread, sometimes over long distances to other orchards. Therefore, we examined the ability of $E$. amylovora to survive in soils and on the surfaces of common materials such as T-shirts, wrist bands, pruning shears, and rubber boots by both conventional PCR (cPCR) and quantitative PCR (qPCR) methods. E. amylovora was detected in all materials tested in this study and survived for sufficiently long periods to cause fire blight disease in new sites. Thus, based on the results of this study, sanitation protocols must be applied to equipment during orchard work.
\end{abstract}

Keywords: Apple, Erwinia amylovora, fire blight, longevity, pear

\section{Introduction}

In 2015, fire blight disease caused by Erwinia amylovora was first reported in apple and pear orchards in Korea in the cities of Anseong, Cheonan, and Jecheon (Myung et al., 2016; Park et al., 2016). This disease spread to previously disease-free orchards within Anseong and Cheonan during 2016 and 2017 even though infested apple and pear trees had been removed and buried according to the sanitation protocols specified in the Plant Protection Act of Korea (Park et al., 2017). In 2018, this disease was almost ubiquitous in orchards in Anseong and Cheonan, and also occurred in 32 orchards in Jecheon. Orchard owners panicked and the government had to spend a lot on compensation to owners for removed trees. One mysterious issue was the absence of the disease from orchards in Jecheon in the two years after 2015. The disease has also been reported in the cities of Wonju

Research in Plant Disease

pISSN 1598-2262, elSSN 2233-9191

www.online-rpd.org and Pyeongchang in Gangwon province in which apple orchards are becoming more popular due to global warming and in the city of Chungju where apples are produced as a local specialty in 2018. Thus, there are six areas (Anseong, Cheonan, Jecheon, Wonju, Pyeongchang, and Chungju) in which fire blight has been observed to date. Fire blight could have serious economic implications for these areas, and also for other apple and pear growing areas that have not yet been affected. Currently, it is unknown how the bacterium spread to previously disease-free orchards within Anseong and Cheonan, and into the new districts and cities of Wonju, Pyeongchang, and Chungju.

The causal bacterium for fire blight disease, E. amylovora, is known to be easily spread by rain, wind, insects, birds, and orchard workers (van der Zwet et al., 2012). Among these vectors, rain and wind in particular wind-driven rain seem to be particularly important for bacterial dissemination over short distances based on research since the early 1900s (Gossard and Walton, 1922; McManus and Jones, 1994; Stevens et al., 1918). Wind and rain also explain some of the patterns of spread from infected orchards to neighboring orchards in 
Korea; for example, the disease has spread from one apple orchard in Wonju that had a high incidence of the disease into a neighboring orchard. However, new incidences of fire blight disease have also occurred in orchards separated by long distances from other orchards where the disease has been observed; this pattern of spread cannot be explained by rain and wind. Based on previous studies, pathogens such as E. amylovora have survived on the bee body for $36 \mathrm{~h}$ in spring, and $48 \mathrm{~h}$ in autumn (Alexandrova et al., 2002). Bees can become vectors of live E. amylovora for up to $48 \mathrm{~h}$ (Sabatini et al., 2006). However, pollinating insects, including bees, are not likely to be the of the fire blight pathogen in the patterns of fire blight occurrence over long distances in Korea. Moreover, it appears that in Korea the major symptom is shoot blight rather than blossom blight which occurs in orchards in European countries and in the United States. Therefore, it seems that pollinating insects are not likely to be the main vectors of the disease spread in Korea. A study at Kangwon National University collected 830 insects from 41 Families and 85 species during 2016-2018 and E. amylovora was only found from only one individual insect, a bee, meaning that dissemination of the pathogen by bees, and other pollinating insects, is very rare (Prof. Kim, personal communication). Thus, human activities, especially the activities of orchard workers, may be considered as one of main agents for spreading fire blight in Korea. If pruning shears and saws used to cut twigs and limbs in the summer and winter seasons are not sterilized, they could act as a means to spread E. amylovora (Keil and van der Zwet, 1967). Additionally, hands, clothing, shoes of orchard workers, and the wheels of orchard equipment may also be ways by which E. amylovora can spread (van der Zwet et al., 2012). Therefore, in this study, we aimed to assess human activity as a means for spread of the fire blight pathogen, E. amylovora, in apple and pear orchards in Korea.

E. amylovora strain TS3128 was used from isolated in infected orchard in Anseong. The strain was developed to spontaneous mutant that was daily cultivated in MGY (mannitol glutamate yeast extract) broth with the antibiotic rifampicin at concentrations of ranged from $1.5 \mu \mathrm{g} / \mathrm{ml}$ to $100 \mu \mathrm{g} /$ $\mathrm{ml}$. Inoculums of E. amylovora spontaneous mutant $(100 \mu \mathrm{g} /$ $\mathrm{ml}$ of rifampicin) were prepared at 0.1 of optical density (OD) $600 \mathrm{~nm}$ in $10 \mathrm{mM} \mathrm{MgCl}$ for different materials (soils, T-shirts, wrist bands, pruning shears, and rubber boots). For T-shirts and wrist bands, eight $1 \mathrm{~cm}^{2}$ portions of the materials were cut and put in a sterilized box. Then inoculum was sprayed to thoroughly wet the materials. A longevity assay was carried out after $5,10,15$, and 20 days post inoculation by suspending $1 \mathrm{ml}$ in $10 \mathrm{mM} \mathrm{MgCl}$ of each portion, and plating with 10 -fold dilutions in three-repeats on KB plates with rifampicin. Before inoculating the pruning shears and rubber boots, the shears and boots were sterilized by autoclaving and disinfected with $70 \%$ ethanol. A 2-cm length section of the shears and boots were marked with a felt-tip pen and that section was sprayed with $E$. amylovora inoculum. Bacteria were counted 3, 6, 12, 24, and $48 \mathrm{~h}$ later as mentioned above except using suspending cotton ball that rubbed marking region. Non-sterilized soils and sterilized by autoclaving soils were prepared and sprayed with E. amylovora inoculum. Bacteria were counted at $3,6,10,15,20,30$, and 40 days post inoculation using the same procedures.

The existence of $E$. amylovora on the surface of these materials were assessed using conventional PCR (CPCR) with AMSbL/R primer sets, and quantitative PCR (qPCR) with E1f/ E2 primer sets (Bereswill et al., 1995; De Bellis et al., 2007). For CPCR, 10 ul of $10^{\circ}$ to $10^{-2}$ suspensions in Nuclease-Free Water (Thermo Fisher Scientific Inc. Waltham, MA, USA) that were boiled for 5 min at $95^{\circ} \mathrm{C}$ of T-shirts, wrist bands, rubber boots, and pruning shears, and 2 ul genomic DNA extracted from soils by Wizard Genomic DNA Purification Kit (Promega Co., WI, USA) were used as templates, and CPCR was carried out with EmeraldAmp ${ }^{\circ}$ GT PCR Master Mix (Takara Bio Inc. Shiga, Japan) by TaKaRa PCR Thermal Cycler Dice Gradient (Takara) following CPCR conditions: hot start for $5 \mathrm{~min}$ at $95^{\circ} \mathrm{C}$, and 35 cycles with $94^{\circ} \mathrm{C}$ for $5 \mathrm{~min}$ for denaturation, $55^{\circ} \mathrm{C}$ for $1 \mathrm{~min}$ for annealing, and $72^{\circ} \mathrm{C}$ for $1 \mathrm{~min}$ for extension, then $72^{\circ} \mathrm{C}$ for 10 min. The amplicon of 1,600 bp of amylovoran biosynthesis glycosyltransferase region was observed on $1 \%$ agarose gel with ethidium bromide staining as positive reaction including that size of weak band because it was confirmed by sequencing. In addition, the same samples were analyzed by qPCR with Real-Time PCR Master Mix (Elpis Biotech, Daejeon, Korea) in StepOnePlus Real-Time PCR System (Applied Biosystems, Foster City, CA, USA) with conditions of $95^{\circ} \mathrm{C}$ for $2 \mathrm{~min}$ for initial denaturation, and 40 cycles of $95^{\circ} \mathrm{C}$ for $5 \mathrm{sec}$ and $55^{\circ} \mathrm{C}$ for $10 \mathrm{sec}$. The results were obtained using amplification plot and melting curve, and determined bacteria detection in case of earlier $\mathrm{Ct}$ values than $25 \mathrm{Ct}$ mean as threshold using StepOne Software v2.3 (Life Technologies, Carlsbad, CA, USA).

The bacterial colony forming units (CFUs) of E. amylovora 

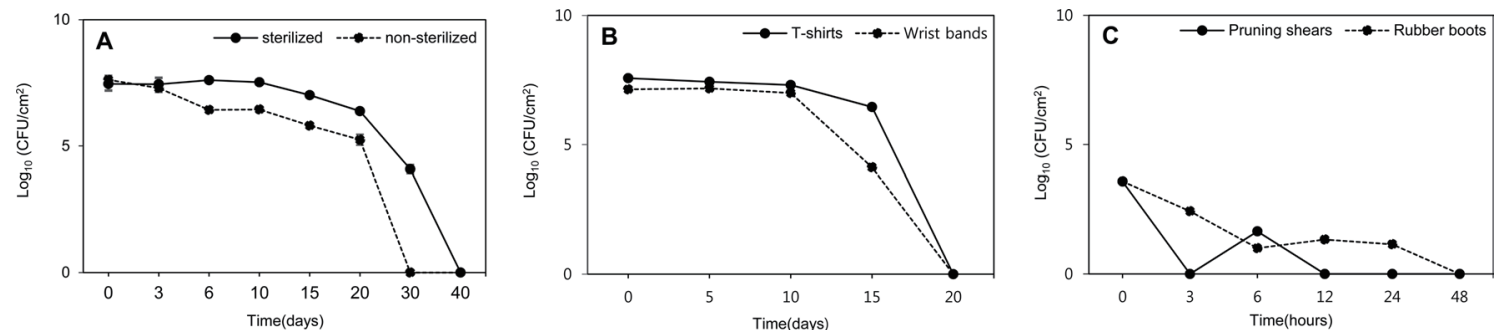

Fig. 1. Bacterial population on MGY medium with rifampicin from suspension of soils (A), T-shirts, and wrist bands (B) and cotton balls rubbed on surface of pruning shears and rubber boots (C).

Table 1. Bacterial detection on soils, T-shirts, wrist bands, pruning shears, and rubber boots using conventional PCR (CPCR)

\begin{tabular}{|c|c|c|c|c|c|c|c|c|}
\hline \multirow{2}{*}{ Day } & \multicolumn{2}{|c|}{ CPCR } & \multirow{2}{*}{ Day } & \multicolumn{2}{|c|}{ cPCR } & \multirow{2}{*}{ Hour } & \multicolumn{2}{|c|}{ cPCR } \\
\hline & Sterilized soil & Non-sterilized soil & & T-shirts & Wrist bands & & Pruning shears & Rubber boots \\
\hline 0 & $+a$ & + & 0 & + & + & 0 & - & - \\
\hline 3 & + & + & 5 & + & + & 3 & - & - \\
\hline 6 & + & + & 10 & + & + & 6 & - & - \\
\hline 10 & - & - & 15 & + & + & 12 & - & - \\
\hline 15 & + & - & 20 & + & + & 24 & - & - \\
\hline 20 & + & - & & & & 48 & - & - \\
\hline 30 & - & - & & & & & & \\
\hline 40 & - & - & & & & & & \\
\hline
\end{tabular}

${ }^{a}+$, predictable band of 1,600 bp size was produced at those times; -, not produced.

decreased gradually until 20 days post-inoculation for nonsterilized soils, and 30 days post-inoculation for sterilized soils (Fig. 1A). Previously, Ark (1932) showed that E. amylovora persist for 54 days in sterilized soil and for 38 days in nonsterilized soil. This was conducted under natural condition where soils were collected from beneath a blighted tree and he only found bacteria from droplets of bacterial exudates. However, earlier studies and our study have shown similar patterns in terms of longevity of bacterium in both natural and artificial conditions, indicating that E. amylovora seems to survive for a long time in soils. Our results also indicated that the rates of bacterial decline were much higher in the non-sterile than in the sterile soil (Hildebrand et al., 2001), suggesting that E. amylovora may face harsher conditions in the rhizosphere due to the antagonistic action of many competing microorganisms. In a test of soils by CPCR, predictable bands of 1,600 bp size were produced until 6 and 20 days post-inoculation from non-sterilized and sterilized soils, respectively, even though bacteria survived longer than detection by it (Table 1). However, qPCR could be amplify higher Ct value than threshold from extracted DNA samples from sterilized soil until 30 days post-inoculation (Fig. 2A) and from non-sterilized soil until 15 days postinoculation (Fig. 2B). Thus, we hypothesize that E. amylovora can persist for longer than 30 days after inoculation in laboratory conditions, and E. amylovora in soils can disseminate to other trees when environmental conditions are favorable for the pathogen.

E. amylovora was also detected on T-shirts and wrist bands at 15 days post-inoculation by population test, and 20 days post-inoculation using CPCR and qPCR (Fig. 1B, 2C and D, Table 1). Human pathogens such as Escherichia, Klebsiella, Pseudomonas, Salmonella, and Staphylococcus have survived for up to $24 \mathrm{~h}$ on clean clothes and they can be transferred in sufficient numbers to cause disease (Scott and Bloomfield, 1990). The plant pathogenic bacterium, Xanthomonas fragariae, has also been detected 4 weeks post inoculation on the surface of T-shirts (Wang et al., 2016). Therefore, the clothes of orchard workers are a high risk for harboring the fire blight pathogen. E. amylovora can be transferred via 

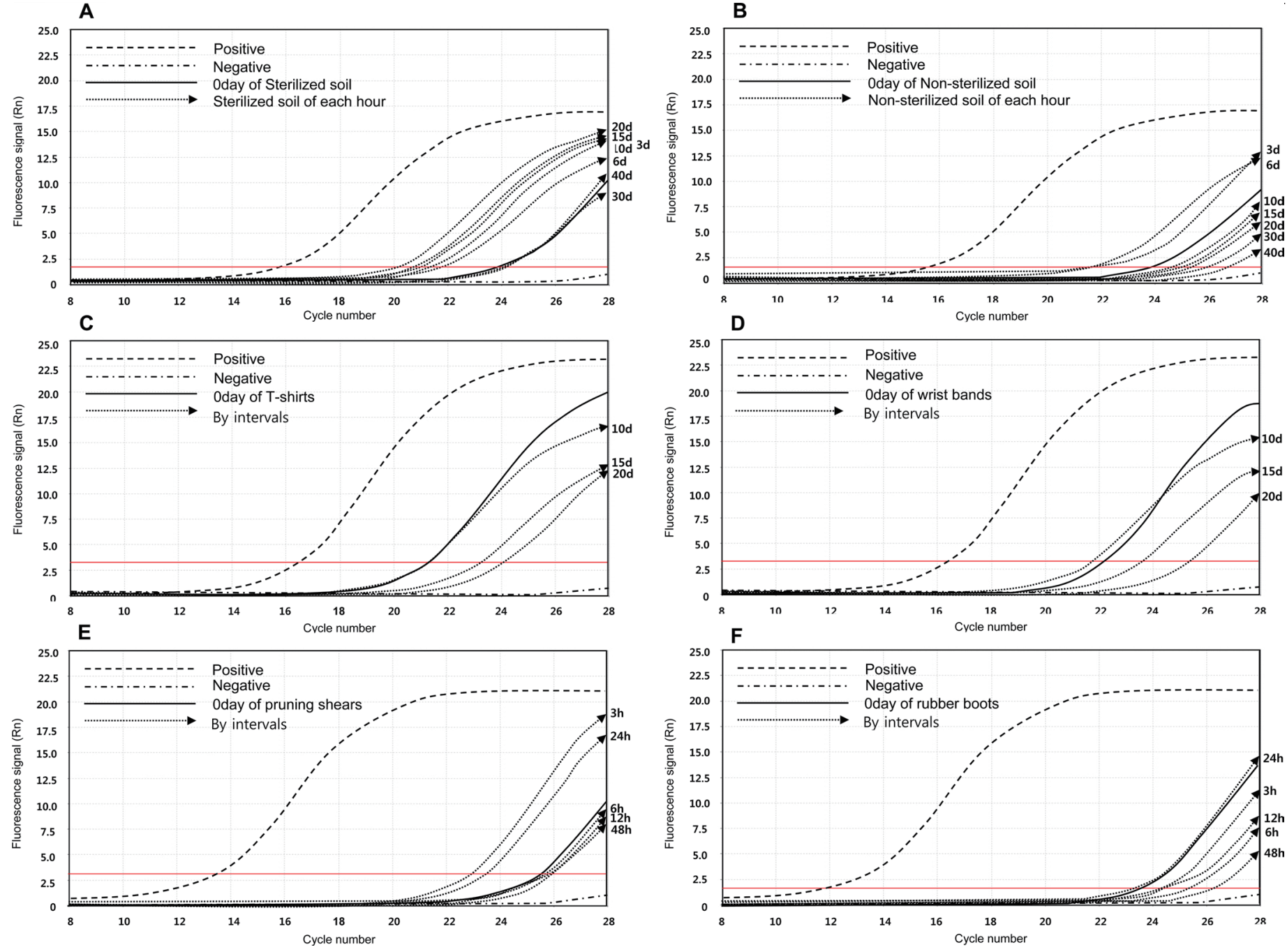

Fig. 2. Bacterial detection on extracted DNAs in soils (A and B), and boiled suspensions of T-shirts (C), wrist bands (D), pruning shears (E) and rubber boots (F) using quantitative PCR (qPCR). E. amylovora cells were detected in all samples tested in this study based on earlier $\mathrm{Ct}$ values than $25 \mathrm{Ct}$ mean as threshold.

clothes and wrist bands into new orchards if farmers do not follow sanitary procedures (e.g., changing and washing their clothes during intensive work times). The other equipment investigated as agents for spreading the pathogen were pruning shears and shoes. Although bacterial populations observed were lower than those of soils and cloths (Fig. 1C), E. amylovora survived for $24 \mathrm{~h}$ from pruning shears and rubber boots as confirmed by qPCR (Fig. 1C, 2E and F, Table 1). Based on observations of orchard work in Korea, farmers do not carefully clean their shears during pruning of shoots and branches, and may even not clean shears when workers move between orchards. Thus, pruning shears and rubber boots are a high risk for spread of fire blight in Korea.

These results are noteworthy because: (i) E. amylovora survived in all materials tested in this study - thus, the pathogen can be transferred to new trees or orchards through the activity of orchard workers over long distances and between orchards; (ii) sanitary procedures should be used to thoroughly clean working tools, other equipment, clothes, and shoes used in orchards; (iii) when soils are transferred, soils should also be thoroughly cleaned; and (iv) the most sensitive method for detecting E. amylovora used in this study was qPCR. However, there are several PCR-based methods to detect E. amylovora, especially peptide nucleic acid (PNA)based PCR developed by the Animal and Plant Quarantine Agency (QIA) of Korea. Thus, monitoring and detection of fire blight pathogen should be performed using highly sensitive detection methods.

Overall, based on this study, orchard workers and officers must implement a sanitation protocol to treat equipment used in orchards. The protocol must be implemented carefully when fire blight disease has been confirmed. 


\section{Conflicts of Interest}

No potential conflict of interest relevant to this article was reported.

\section{Acknowledgements}

This work was carried out with the support of the "Cooperative Research Program for Agriculture Science \& Technology Development (Project No: PJ011758032018), and was also supported by a 2016 Research Grant from Kangwon National University (No. 520160461), and by a grant from the Basic Science Research Program through the National Research Foundation of Korea (NRF) funded by the Ministry of Education (No. 2018R1A6A1A03025582) to Yeon-Jeong Lim.

\section{References}

Alexandrova, M., Porrini, C., Bazzi, C., Carpana, E., Bigliardi, M. and Sabatini, A. G. 2002. Erwinia amylovora longevity in beehives, beehive products and honeybees. Acta Hortic. 590: 201-205.

Ark, P. A. 1932. The behavior of Bacillus amylovorus in the soil. Phytopathology 22: 657-660.

Bereswill, S., Bugert, P., Bruchmüller, I. and Geider, K. 1995. Identification of the fire blight pathogen, Erwinia amylovora, by PCR assays with chromosomal DNA. Appl. Envriron. Microbiol. 61: 2636-2642.

De Bellis, P., Schena, L. and Cariddi, C. 2007. Real-time scorpionPCR detection and quantification of Erwinia amylovora on pear leaves and flowers. Eur. J. Plant Pathol. 118: 11-22.

Gossard, H. A. and Walton, R. C. 1922. Dissemination of fire blight. Ohio Agricultural Experiment Station, Wooster, Ohio, USA. 126 pp.

Hildebrand, M., Tebbe, C. C. and Geider, K. 2001. Survival studies with the fire blight pathogen Erwinia amylovora in soil and in a soil-inhabiting insect. J. Phytopathol. 149: 635-639.

Keil, H. L. and van der Zwet, T. 1967. Sodium hypochlorite as a disinfectant of pruning tools for fire blight control. Plant Dis. Rep. 51: 753-755.

McManus, P. S. and Jones, A. L. 1994. Role of wind-driven rain, aerosols, and contaminated budwood in incidence and spatial pattern of fire blight in an apple nursery. Plant Dis. 78: 1059-1066.

Myung I.-S. Lee, J.-Y., Yun, M.-J., Lee, Y.-H., Lee, Y.-K. and Park, D.-H. et al. 2016. Fire blight of apple, caused by Erwinia amylovora, a new disease in Korea. Plant Dis. 100: 1774.

Park, D. H., Lee, Y.-G., Kim, J.-S., Cha, J.-S. and Oh, C.-S. 2017. Current status of fire blight caused by Erwinia amylovora and action for its management in Korea. J. Plant Pathol. 99: 59-63.

Park, D. H., Yu, J.-G., Oh, E.-J., Han, K.-S., Yea, M. C., Lee, S. J. et al. 2016. First report of fire blight disease on Asian pear caused by Erwinia amylovora in Korea. Plant Dis. 100: 1946.

Sabatini, A., G., Alexandrova, M., Carpana, E., Medrzycki, P., Bortolotti, L., Ghini, S. et al. 2006. Relationship between Apis mellifera and Erwinia amylovora: Bioindication, bacterium dispersal, and quarantine procedures. Acta Hortic. 704: 155-162.

Scott, E. and Bloomfield, S. F. 1990. The survival and transfer of microbial contamination via cloths, hands and utensils. J. Appl. Bacteriol. 68: 271-278.

Stevens, F. L., Ruth, W. A. and Spooner, C. S. 1918. Pear blight wind borne. Science 48: 449-450.

van der Zwet, T., Orolaza-Halbrendt, N. and Zeller, W. 2012. Fire blight: History, biology, and management. APS press, St. Paul, MN, USA. 421 pp.

Wang, H., Gigot, C., McRoberts, N. and Turechek, W. W. 2016. Inoculum sources of Xanthomonas fragariae in strawberry nursery packing houses: presence, viability and transmission. Phytopathology 106:S4.77. 